\title{
Alaska's Mineral Industry 1992: A Summary
}

by R.C. Swainbank, T.K. Bundtzen, A.H. Clough, and E.W. Hansen

-PRODUCTION-Metals, industrial minerals, and coal, with an estimated value of $\$ 561$ million, was steady with 1991 value. Low commodity prices reduced profitability for most Alaska mines.

-EMPLOYMENT-3,492 full-timeequivalent jobs, about the same as 1991.

-EXPLORATION-Expenditures decline to $\$ 30.4$ million. up from 1991 expenditures.

\section{-HEALY CLEAN COAL} TECHNOLOGY PROJECTAdvanced during 1992.

-LAND SELECTION-State proceeded with applications for final selections and access provisions from federal government according to the provisions of the 1959 Alaska Statehood Act.

-RENTS-New federal rules require rents on federal mining claims.
-DEVELOPMENT - \$29.6 million,

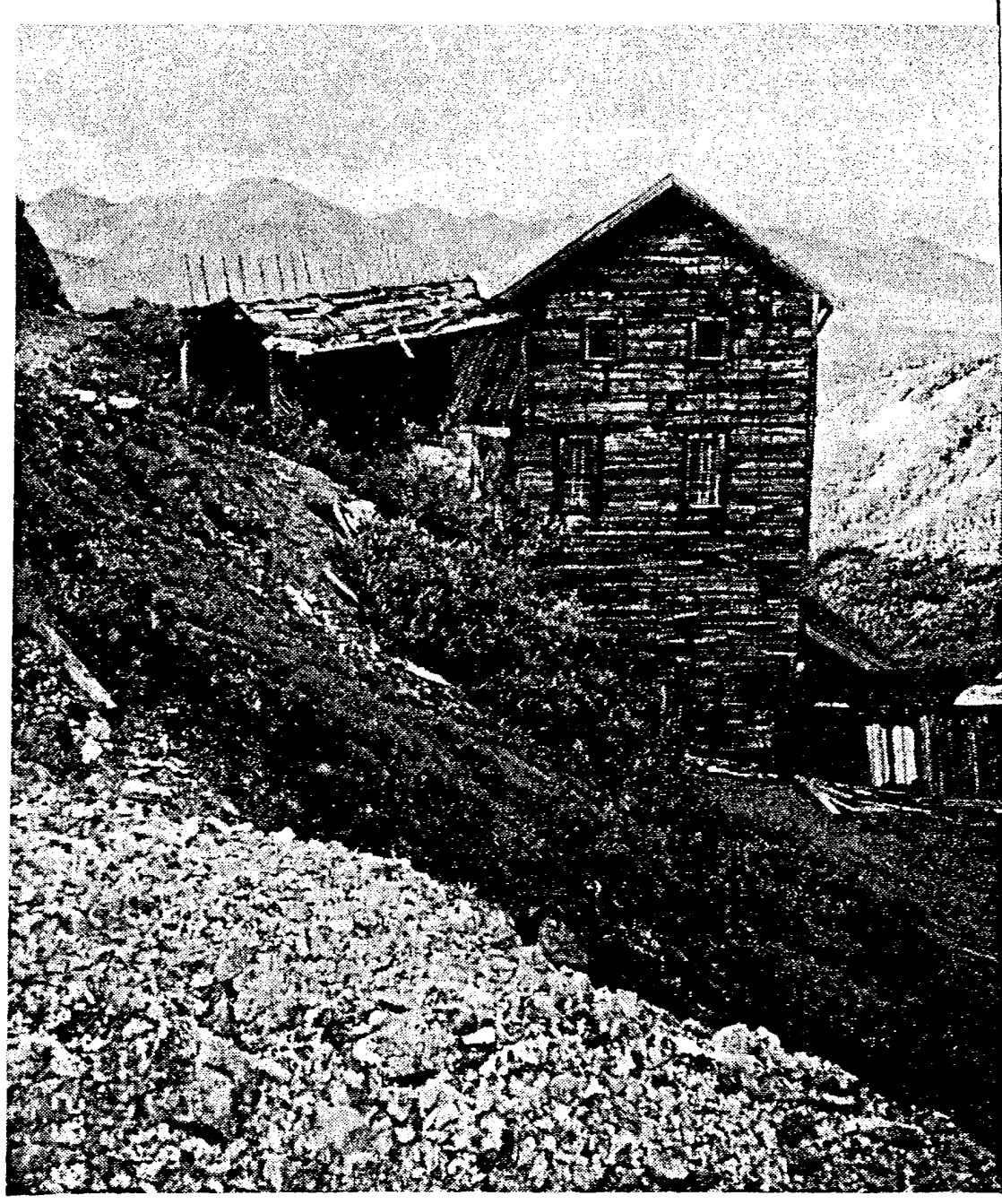

DIVISION OF GEOLOGICAL \& GEOPHYSICAL SURVEYS

INFORMATION CIRCULAR 36

March 1993 


\title{
Alaska's Mineral Industry 1992: A Summary
}

by

\author{
R.C. Swainbank, T.K. Bundtzen, ${ }^{2}$ A.H. Clough, ${ }^{3}$ and E.W. Hansen ${ }^{4}$
}

This summary is a preliminary review of mineral industry activity in Alaska during 1992. Much of the information it contains is based on partial returns of a Division of Geological \& Geophysical Surveys (DGGS) questionnaire circulated in late 1992. The purpose of the summary is to provide timely information, pending publication of the complete annual report later this year.

Table 1 summarizes the value of mineral production and reported expenditures for exploration and development during the last four years.

Although production from individual mines varied somewhat from the previous year, the total value of mineral production for 1992 is estimated at $\$ 560.8$ million, up 3 percent from 1991. Production of placer gold at Cambior Alaska Inc.'s Valdez Creek Mine was $2,676 \mathrm{~kg}(86,052 \mathrm{oz})$ refined gold, the largest production year thus far during the eight-year mine development. In the third quarter of 1992 Cominco Alaska Inc. reported substantial improvement in zinc recovery at the Red Dog Mine.

Development projects at Greens Creek Mine in 1992 resulted in more effective separation of mineral concentrates. (However, at this writing, Kennecott Greens Creek Mining Company has announced that the mine will close in April 1993 because of depressed metal prices and will reopen only when metal prices improve substantially. During this shutdown, limited underground exploration and development will be ongoing to facilitate reopening of the mine.)

Other noteworthy mineral development projects in 1992 were reported at the Fort Knox gold deposit near Fairbanks, at the Valdez Creek gold placer mine, and at Idemitsu-Alaska Inc.'s Wishbone Hill coal property. Total expenditures on mineral development in 1992 were $\$ 29.6$ million, up from $\$ 25.6$ million reported in 1991 .

Reported exploration expenditures were $\$ 30.4$ million, down from $\$ 39.9$ million reported in 1991 . Hence, the

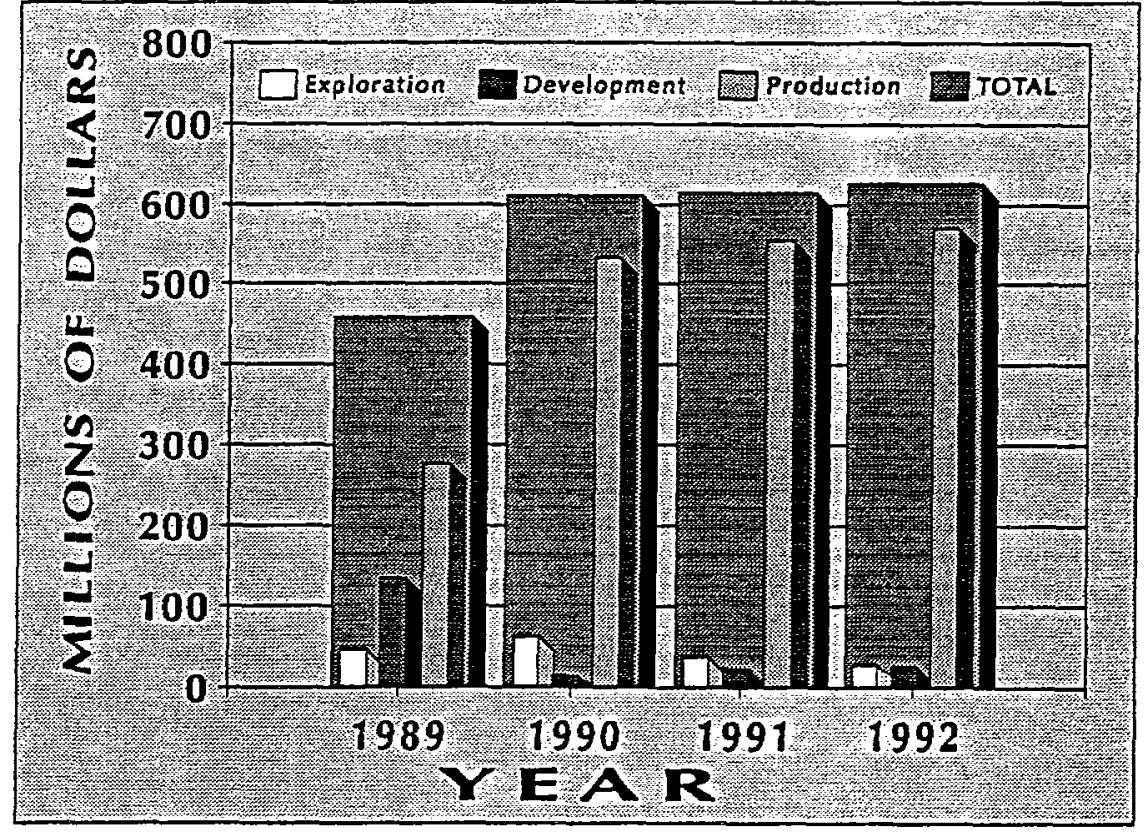

Alaska Mineral Industry Activity, 1988-1991.

\footnotetext{
${ }_{1}^{1}$ Deparment of Commerce \& Economic Development, Division of Economic Development, 1001 Noble Street. Suite 360. Fairbanks, AK 99701. ${ }^{2}$ Department of Natural Resources, Division of Geological \& Geophysical Surveys, 794 University Avenue, Suite 200, Fairbanks, AK 99709. ${ }^{3}$ Department of Commerce \& Economic Development, P.O. Box 110804, Juneau, AK 99811-0804.

${ }^{4}$ Department of Nanural Resources, Division of Mining, 3700 Aipport Way, Fairtanks, AK 99709.
} 
total preproduction investments reported in 1992 were $\$ 60.0$ million, compared with $\$ 65.5$ million reported for 1991 .

Exploration highlights include significant expansion of reserves or resources at Illinois Creek, at the Ryan Lode, and at Johnson River. New projects were reported in the Rampart, Upper Salcha, and Ladue River areas.

State estimates show that 3,494 people were employed in all aspects of the mineral industry during 1992 , compared with about 3,646 employed in 1991. The 4 percent decrease was caused mainly by lower exploration levels (table 2).

Notable federal government actions in 1992 included drastic increases in filing fees and holding fees for federal claims and renewed congressional initiatives to implement large royalties on minerals extracted from these claims. At the state level, following a two-year review of the mineral potential of available federal lands, the state began to make its final selections in late 1992 pursuant to its land entitlement. The state also defined a procedure to nominate rights-of-way under the Revised Statute 2477 (RS2477) provision to allow access across federal lands. The Alaska legislature provided a permanent exemption of in-place natural resources from municipal taxation.

Division of Mining preliminary estimates for 1992 show that 2,501 new state claims and 679 new federal claims were recorded compared with 3,391 and 1,299 , respectively, in 1991. Preliminary estimate of the total active claims for 1992 is 50,049 , compared with 57,666 in 1991; of these 29,116 are state, and 20,933 are federal.

\begin{tabular}{|c|c|c|c|c|}
\hline & 1989 & 1990 & 1991 & 1992 \\
\hline Exploration & $\$ 47,762,596$ & $\$ 63,255,594$ & $\$ 39,908,539$ & $\$ 30,400,000$ \\
\hline Development & $134,272,350$ & $14,326,500$ & $25,574,350$ & $29,590,300$ \\
\hline Production & $276,983,741$ & $533,024,500$ & $546,468,907$ & $560,826,400$ \\
\hline TOTAL & $\$ 459,018,687$ & $\$ 610,606,594$ & $\$ 611,951,796$ & $\$ 620,816,700$ \\
\hline
\end{tabular}

Table 2. Alaskan mine employment, 1989-92

\begin{tabular}{|c|c|c|c|c|}
\hline & 1989 & 1990 & 1991 & 1992 \\
\hline \multicolumn{5}{|l|}{ Gold/silver/mining } \\
\hline Placer & 1,316 & 1,151 & 1,240 & 1,251 \\
\hline Lode & 161 & 265 & 235 & 240 \\
\hline Base metals & 407 & 425 & 415 & 415 \\
\hline Recreational & 325 & 315 & 320 & 325 \\
\hline Sand \& gravel & 625 & 645 & 685 & 640 \\
\hline Building stone & 148 & 160 & 165 & 145 \\
\hline Coal & 120 & 115 & 115 & 115 \\
\hline Peat & $\cdots$ & - & 45 & 40 \\
\hline \multicolumn{5}{|l|}{ Tin, jade, soap-stone, } \\
\hline ceramics, platinum & 40 & 40 & 25 & 20 \\
\hline Mineral development & 785 & 95 & 133 & 164 \\
\hline Mineral exploration & 350 & 374 & 268 & 137 \\
\hline TOTAL & 4,277 & $\mathbf{3 , 5 8 5}$ & 3,646 & 3,492 \\
\hline $\begin{array}{l}--=\text { Information not } \\
{ }^{\mathrm{a}} \mathrm{Calculated} \text { on a } 260-\end{array}$ & tk year. & . & & \\
\hline
\end{tabular}

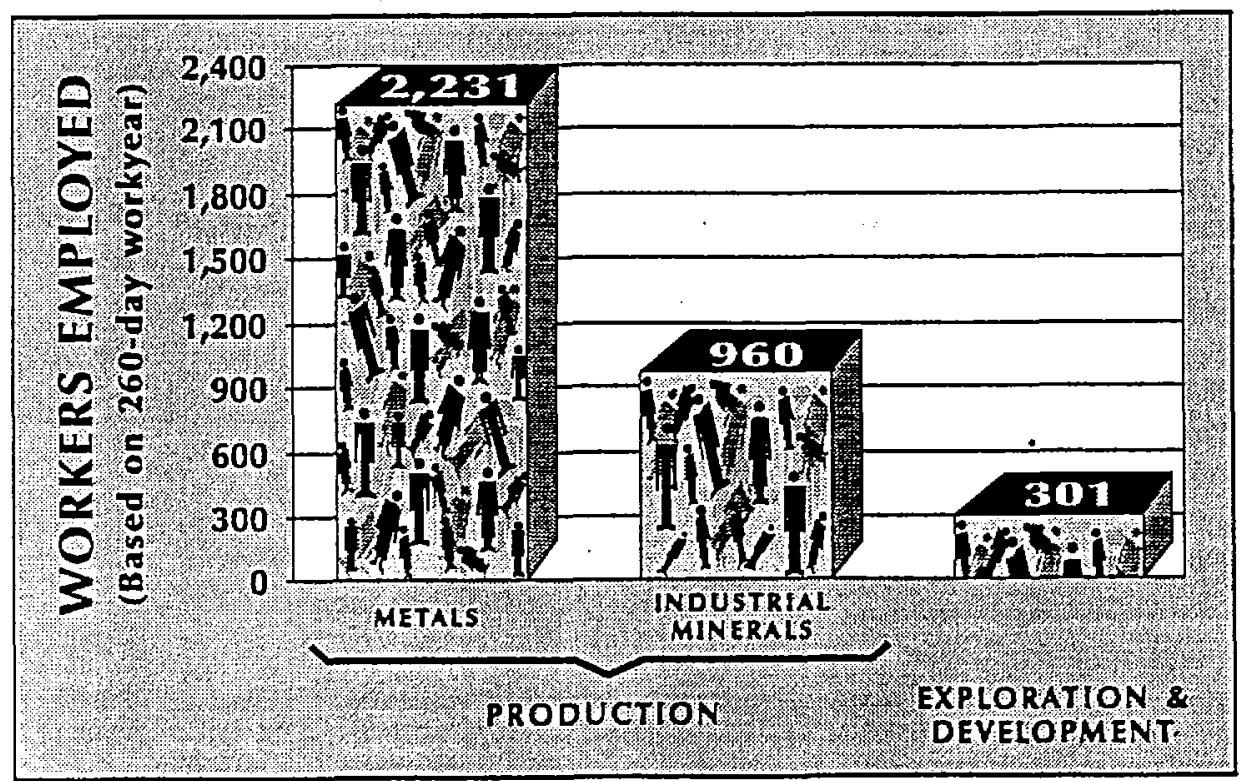

Mineral industry jobs, by category, 1991. 


\section{Production

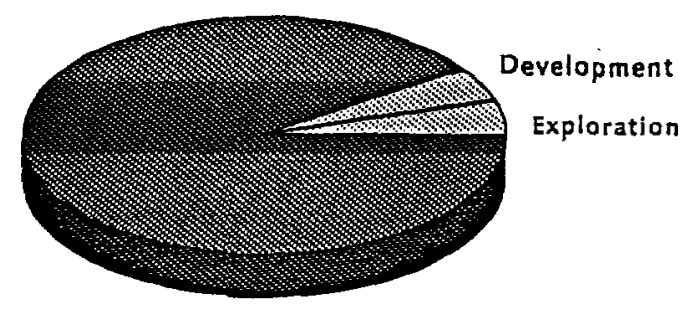

Production of six metals-zinc, gold, silver, lead, tin, and platinum-accounted for 81 percent of total Alaskan mineral production during 1992, an increase of 4 percent from the 1991 level (table 3). However, low metal commodity prices continued to reduce the profitability of most Alaska mines. The average 1992 price for zinc increased 8 percent from 1991 levels; however, the prices of silver, lead and gold dropped 6,4 , and 7 percent, respectively. The value of zinc ( $\$ 302$ million) accounted for 54 percent of Alaska mineral production.

In northwestern Alaska, Cominco Alaska, operator of the NANA Corporation-owned Red Dog deposit, shipped 429,901 tonnes ( 473,000 tons) of zinc, lead, and ISF composite metal concentrate in 1992. This amount is close to the concentrate tonnage shipped in 1991. As in previous years, the concentrates were trucked from mine site to the Kivalina Port, where they were transported during the August to October shipping season to the Cominco smelter at Trail, British Columbia and overseas locations. By implementing technology that selectively processes individual ore types separately, Cominco improved the quality of zinc concentrates at Red Dog, North America's largest producer of zinc. The company reported that overall mill head grades during 1992 were 19.9 percent zinc, 6.0 percent lead, and $99 \mathrm{~g} /$ tonne $(2.9 \mathrm{oz} /$ ton $)$ silver.

Kennecott Greens Creek Mining Company produced 103,241 tonnes $(113,827$ tons) sulfide concentrates that contained 36,733 tonnes ( 40,500 tons) zinc, 14,966 tonnes $(16,500$ tons) lead, $217,700 \mathrm{~kg}$ $(7,000,000 \mathrm{oz})$ silver, and $1,008 \mathrm{~kg}(32,400 \mathrm{oz})$ gold. Despite another high yield production year, Kennecott reported another loss for the 1992 calendar year.

Despite difficult economic conditions at both mines, the Greens Creek and Red Dog operations produced about half of the U.S. domestic mine production of zinc, 12 percent of the lead, and 17 percent of the silver for the 1992 calendar year.

Zinc was the most valuable commodity produced in Alaska, followed by gold. Gold production in 1992 is estimated at $8,163 \mathrm{~kg}(262,500 \mathrm{oz})$ compared with $7,585 \mathrm{~kg}(243,800 \mathrm{oz})$ in 1991, a weight increase of 7 percent. Lower gold prices in 1992 resulted in nearly the same estimated value ( $\$ 88$ million) for the two

March 1993 reporting years. Production came from 197 placer and two lode mines, compared with 202 placer and two lode mines that reported production in 1991.

Cambior Alaska's Valdez Creek mine east of Cantwell produced an estimated $2,676 \mathrm{~kg}(86,052 \mathrm{oz})$ of refined gold making it Alaska's largest gold mine for seven of the last eight years. Rounding out the top ten producers (not necessarily in order) were: Greens Creek Mine, southeast Alaska; Polar Mining, Fairbanks; the Dredges of Alaska Gold Company, Nome; Alaska Placer Development, Livengood; Taiga Mining, Hogatza; NYAC Mining, Ariak; Cooks Mining, Fairbanks; Sphinx America, Ruby; and Paul and Company, Circle.

A late spring and early winter in Alaska's interior caused many seasonal placer mining firms to lose up to 25 percent of seasonal annual production. Nevertheless, reported unit-cost performance improved from

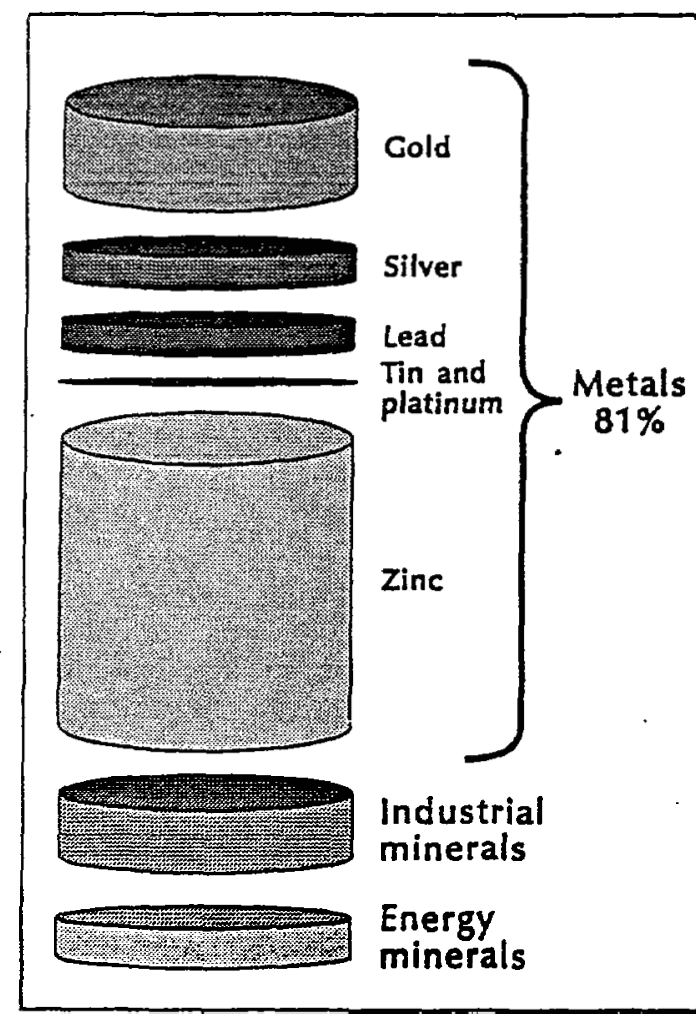

Estimated Alaskan mineral production in 1992 totaled $\$ 560.8$ million.

Information Circular 36 


\begin{tabular}{|c|c|c|c|c|c|c|}
\hline \multirow[b]{2}{*}{ Metals } & \multicolumn{3}{|c|}{ Quantity } & \multicolumn{3}{|c|}{ Estimated values } \\
\hline & 1990 & 1991 & 1992 & 1990 & 1991 & 1992 \\
\hline Gold (ounces) & 231,700 & 243,900 & 262,500 & $\$ 89,204,000$ & $\$ 88,291,800$ & $\$ 88,463,000$ \\
\hline (kilograms) & 7,206 & 7,585 & 8.163 & & & \\
\hline Silver (ounces) & $10,135,000$ & $9,076,854$ & $9,115,755$ & $50,675,000$ & $39,114,490$ & $34,913,341$ \\
\hline (kilograms) & 315,199 & 281,382 & 283,500 & & & \\
\hline Platinum (ounces) & $\cdots$ & 15 & w & $\cdots$ & 5,325 & W \\
\hline (grams) & - & 465 & $\mathrm{~W}$ & . & .. & W \\
\hline Lead (tons) & 44,220 & 69,591 & 68,664 & $30,954,000$ & $33,403,680$ & $31,585,440$ \\
\hline (tonnes) & 40,106 & 63,119 & 62,278 & & & \\
\hline Zinc (tons) & 181,200 & 278,221 & 274,507 & $253,680,000$ & $278,221,000$ & $301,957,700$ \\
\hline (tonnes) & 164,350 & 252,346 & 248,978 & & & \\
\hline Tin (pounds) & 57,000 & 6,800 & 1,500 & 200,000 & 22,100 & 5,910 \\
\hline (kilograms) & 25,855 & 3,084 & 680 & & & \\
\hline Subtotal & & & & $\overline{\$ 424,713,000}$ & $\overline{\$ 439,058,395}$ & $\overline{\$ 456,925,391}$ \\
\hline \multicolumn{7}{|l|}{ Industrial minerals } \\
\hline Jade and soapstone (tons) & W & 16.0 & 1.5 & $W$ & 12,000 & 30,000 \\
\hline (tonnes) & W & 14.5 & 1.4 & & & \\
\hline Sand and gravel (million tons) & 15.0 & 14.2 & 14.6 & $40,821,500$ & $45,448,512$ & $42,200,000$ \\
\hline (million tonnes) & 13.6 & 12.8 & 13.2 & & & \\
\hline Building stone (million tons) & 3.2 & 3.0 & 2.9 & $22,100,000$ & $22,500,000$ & $22,971,000$ \\
\hline (million tonnes) & 2.9 & 2.7 & 2.6 & & & \\
\hline Subtotal & & & & $\overline{\$ 62,921,500}$ & $\$ 67,960,512$ & $565,201,000$ \\
\hline \multicolumn{7}{|l|}{ Energy minerals } \\
\hline Coal (tons) & $1,576,000$ & $1,540,000$ & $1,531,000$ & $\$ 44,990,000$ & $\$ 39,000,000$ & $\$ 38,300,000$ \\
\hline (tonnes) & $1,429,000$ & $1,396,780$ & $1,388,620$ & & & \\
\hline Peat (cubic yards) & 65,000 & 75,000 & 70,000 & 400,000 & 450,000 & 400,000 \\
\hline (cubic meters) & 49,699 & 57,345 & 53,552 & & & \\
\hline Subtotal & & & & $\overline{\$ 45,024,500}$ & $\overline{\$ 39,450,000}$ & $\overline{\$ 38,700,000}$ \\
\hline \multicolumn{4}{|l|}{ TOTAL } & $\$ 533,024,500$ & $\$ 546,468,907$ & $\$ 560,826,391$ \\
\hline \multicolumn{7}{|c|}{$\begin{array}{l}\text { Production data from DGGS questionnaires, USBM file data, phone interviews with mine operators, Alaska Department of Transportation and } \\
\text { Public Facilities, and other sources. } \\
\text { balues calculated from } 1992 \text { average prices of gold }(\$ 337 / \mathrm{oz}) \text {, zinc }(\$ 0.55 / \mathrm{b}) \text {, lead }(\$ 0.23 / \mathrm{b}) \text {, silver, }(\$ 3.83 / \mathrm{oz}) \text {, and tin }(\$ 3.94 / 1 \mathrm{~b}) \text {; all other values } \\
\text { provided by mine operators. } \\
\therefore=\text { Not reported. }\end{array}$} \\
\hline $\begin{array}{l}\therefore=\text { Not reported } \\
\mathrm{w}=\text { Withheld }\end{array}$ & . & & & & & \\
\hline
\end{tabular}

10 to 25 percent from 1991 . The 1992 unit-cost improvement suggests that placer miners may be increasing their overall productivity.

The Alaska sand and gravel industry quarried an estimated 13.2 million tonnes (14.6 million tons), worth $\$ 42.2$ million for Native, state, and federal road construction projects in all regions of Alaska.

Coal production remained about the same as in 1991 -an estimated $1,388,600$ tonnes (1,531,000 tons) worth $\$ 38.3$ million. Most of the production came from the Usibelli Coal mine at Healy where roughly half the coal fuels six interior power plants, and the other half is Alaska Mineral Industry Report: A Summary exported to South Korea. Arctic Slope Consulting Group mined about 680 tonnes ( 750 tons) of coal for testing in village stoves and for metallurgical programs. Price reductions in the international coal markets resulted in more difficult contract negotiations between KEPCO, the South Korean export coal buyer, the Usibelli Coal Mine Inc., the Alaska Railroad, and Sun Eel Shipping Company. 
Exploration

Mineral development expenditures increased 16 percent from $\$ 25.5$ million in 1991 to $\$ 29.6$ million in 1992 (table 4). Most of the increase can be attributed to mine-site work by Fairbanks Gold Mining Inc. at the Fort Knox deposit near Fairbanks and geotechnical improvements at Greens Creek mine near Juneau.

Fairbanks Gold Mining Inc., an operating subsidiary of AMAX Gold Inc., continued to develop the Fort Knox gold deposit, which is situated almost entirely on lands owned by the State of Alaska. The company completed $20,420 \mathrm{~m}(67,000 \mathrm{ft})$ of reverse circulation drilling, conducted geotechnical and hydrologic studies, and completed an on-site condemnation program that identified nonmineralized areas for mill-site design. A comprehensive environmental assessment prepared by $\mathrm{CH}_{2} \mathrm{M}$ Hill for Fairbanks Gold Mining was publicly reviewed throughout the fall of 1992. The Fort Knox mine is expected to cost $\$ 220$ million to develop, produce about $9,330 \mathrm{~kg}(300,000 \mathrm{oz})$ of gold annually-which will roughly double current Alaskan gold production-and employ 250 workers for 16 years. Fairbanks Gold Mining has a projected 1995 startup date.

Kennecott-Greens Creek Mining Company enhanced and modified its water quality containment facility, completed a regrind-flotation expansion project, installed a state-of-the-art waste water treatment facility, and built two tower mills and three additional columnflotation cells. Kennecott carried out this extensive development improvement program despite substantial financial losses.

Idemitsu Alaska Inc. continued development of the Wishbone Hill coal project near Palmer, despite continued uncertainty of the Alaska Mental Health injunction and declining international coal prices. The 1992 work included drilling, engineering studies, ongoing environmental monitoring, and reserve evaluation. To date, Idemitsu has spent $\$ 10$ million to define the coal reserve and complete permitting and engineering studies

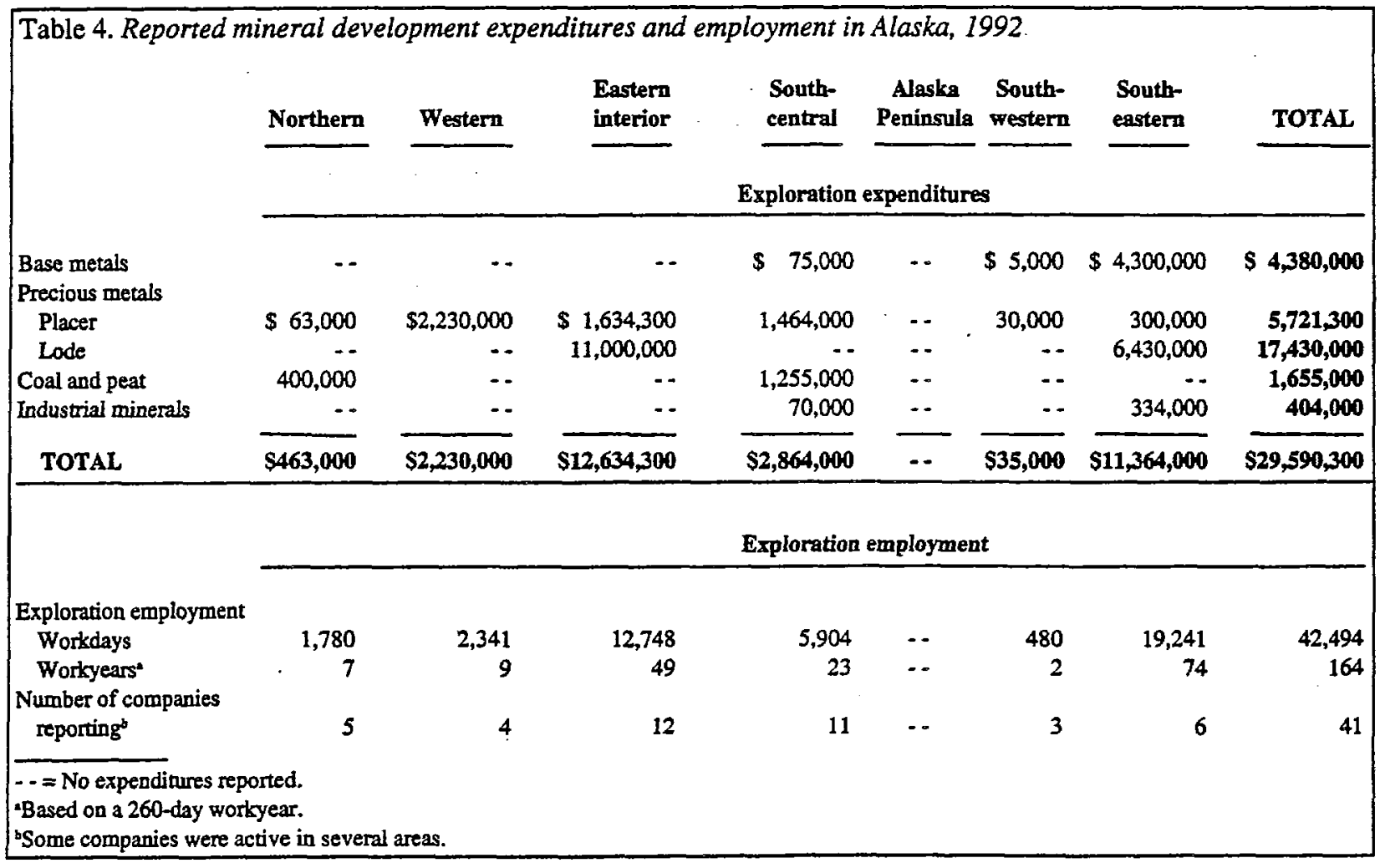




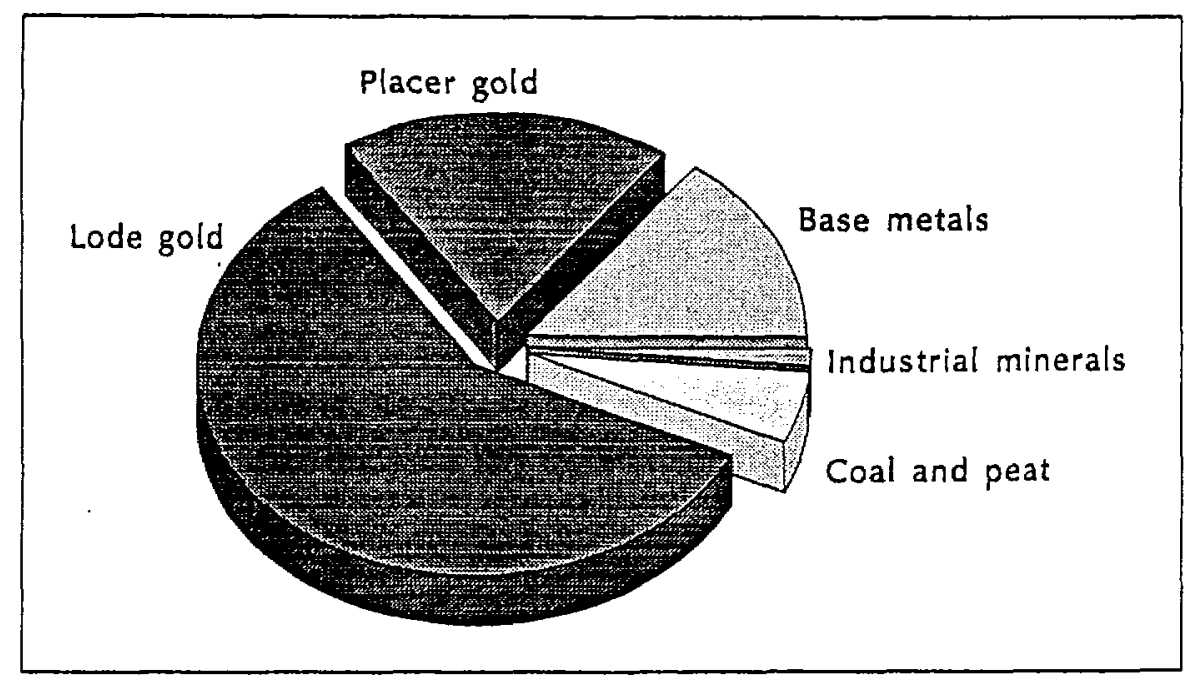

Estimated Alaskan development expenditures for 1992 totaled $\$ 29.6$ million.

for production. Because steam-coal prices have declined, projected costs for the proposed Wishbone Hill mine have been reduced through mine redesign. Idemitsu is evaluating transportation and options of the project to further reduce cost. In production, the mine would export 680,250 tonnes ( 750,000 tons) to Japan and provide 150 to 200 jobs annually.

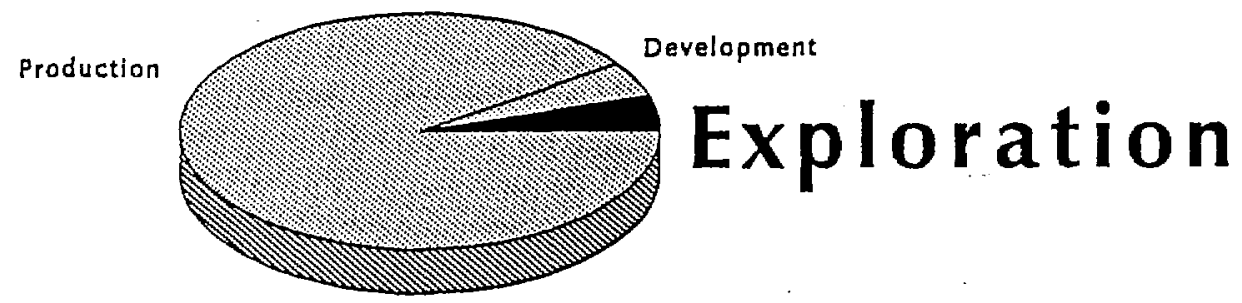

Estimated exploration expenditures for 1992 are $\$ 30.4$ million down substantially from the $\$ 39.9$ million reported in 1991. As was noted earlier in this report, there was an increase in development expenditure as some large projects changed from exploration to development. The exploration estimates are based on responses from 80 mining companies and consultants, the same number of companies that reported back to DGGS in 1991. Table 5 shows the regional distribution of these exploration expenditures.

Although Battle Mountain Exploration Co. had no activity in Alaska in 1992, all of the other companies active in 1991 had significant projects in 1992. Companies which have not been active in Alaska recently, but had large programs in 1992, include Newmont Exploration Ltd. and Noranda Exploration Inc.

\section{Northern Alaska}

Reported exploration expenditures in northern Alaska were up 24 percent in 1992 over those in 1991. As in past years, Arctic Slope Consulting Group had a large drilling program to increase reserves at the Dead- fall Syncline and extracted 680 tonnes ( 750 tons) of the high rank coal for village testing and consumption.

Earth scientists from the U.S. Bureau of Mines, the U.S. Geological Survey, and the State Division of Geological \& Geophysical Surveys continued a multi-year assessment of the north flank of the Brooks Range along the extension of the rock package which hosts the Red Dog Mine. Silverado Mines Ltd. started a drilling project on its Nolan Creek bench property near Wiseman and confirmed the expected grade.

\section{Western Alaska}

Expenditures in western Alaska were down 20 percent from 1991. The Bering Straits Native Corporation (BSNC) had programs in joint venture with Newmont Exploration Ltd. around the Rock Creek prospect and with Kennecott Exploration north of Nome. BSNC also reported work at Mt. Distin and other areas of the Seward Peninsula. North Pacific Mining Co. (NPMC), a subsidiary of the Cook Inlet Regional Corporation (CIRI), was also active on the Seward Peninsula. CIRI is one of the 12 regional Native corporations formed by 
the Alaska Native Claims Settlement Act (ANCSA). The 12 Native corporations hold mineral rights to almost 44 million acres.

NPMC had a large program at the Illinois Creek gold-silver deposit, with $1,530 \mathrm{~m}(5,020 \mathrm{ft})$ of trenching and $1,529 \mathrm{~m}(5,016 \mathrm{ft})$ of diamond drilling completed in 1992. Near-surface geologic resources at Ilinois Creek are reported to be 3.7 million tonnes ( 4.1 million tons) at $2.4 \mathrm{~g} /$ tonne $(0.071 \mathrm{oz} /$ ton $)$ gold and $50 \mathrm{~g} /$ tonne (1.47 oz/ton) silver.

NANA Corporation had a modest geochemical and geophysical exploration program on the Seward Peninsula in 1992, and plans further work next year.

\section{Eastern Interior}

Reported expenditures were up 53 percent from 1991 in the eastern interior of Alaska. Several exploration projects in the Fairbanks, Circle, Livengood, and Richardson mining districts concentrated on the search for bulk mineable gold deposits. At the Ryan Lode on Ester Dome west of Fairbanks, La Teko Resources Ltd. continued a major drilling project, and at the end of 1992 announced a proven and probable resource base of $32,375 \mathrm{~kg}(1,041,000 \mathrm{oz})$ of gold, with a geologic resource of $62,200 \mathrm{~kg}$ ( 2 million oz) in extensions of the identified shear zones in a quartz porphyry pluton and surrounding schist. American Copper and Nickel Co. continued an aggressive exploration program on the remaining $36 \mathrm{sq} \mathrm{km}$ (14 sq $\mathrm{mi}$ ) of Ester Dome and at the nearby Eagle Creek prospect, where gold is also spatially related to intrusive rocks, similar to deposits on Ester Dome. Freegold Recovery Ltd. continued its exploration of a series of prospects within a large landholding at Cleary Summit in the eastern part of the district, and reached an agreement-in-principle with AMAX Gold Inc. early in 1993 for further exploration. AMAX also continued exploration at the Liberty Bell Mine in the Bonnifield district and west of Pedro Dome in the Fairbanks district.

Tri-Valley Corporation, in joint venture with the Russian TsNIGRI group, continued evaluation of its $179 \mathrm{sq} \mathrm{km}$ (70 sq mi) land base in the Richardson District, about $113 \mathrm{~km}$ ( $70 \mathrm{mi}$ ) east of Fairbanks.

In the Circle mining district, about $160 \mathrm{~km}(100 \mathrm{mi})$ north of Fairbanks, several groups are prospecting highgrade gold veins and an igneous-hosted gold prospect in the Portage Creek drainage. At the end of 1992, Verdstone Gold Corp. optioned claims near Crooked Creek where three diamonds were recovered from placer gold mines in the mid-1980s.

Montague Gold NL, in a joint venture with ASA Inc., an Alaskan company with Australian and Scottish involvement, has been exploring several blocks of land owned by Doyon Inc., a Fairbanks-based Native corporation. Late in 1992, the joint venture acquired some state land at Sawtooth Mountain west of Livengood, where vein samples with $51 \mathrm{~g} /$ tonne $(1.49 \mathrm{oz} / \mathrm{ton})$ gold occur, and where a veined pyrite-bearing monzonite crops

Table 5. Reported exploration expenditures and employment in Alaska by commodity and region, 1992

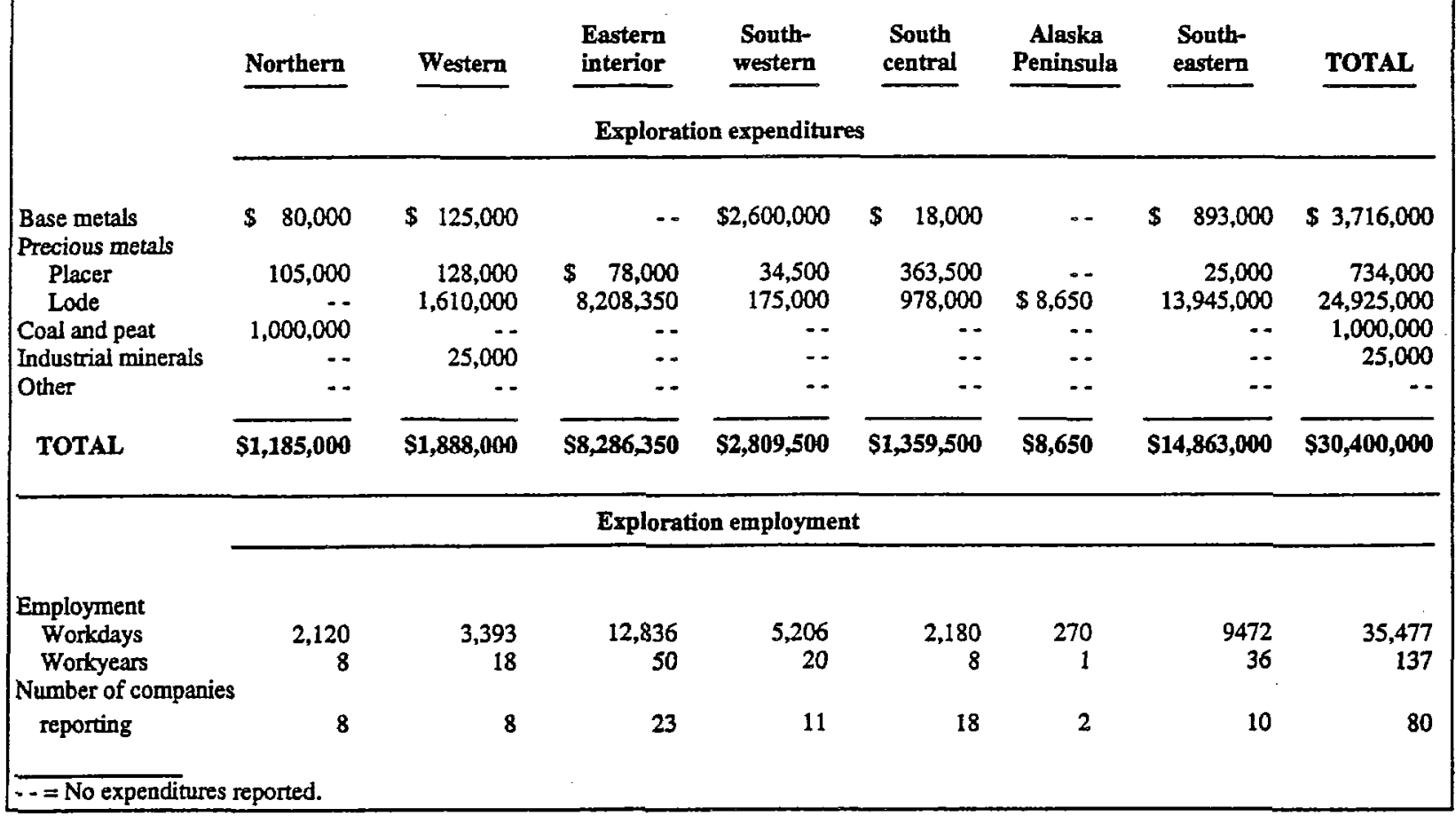


out with gold values up to $13.0 \mathrm{~g} /$ tonne $(0.38 \mathrm{oz} /$ ton $)$. Placer Dome US Inc. has an adjacent land holding. ASA Inc. was also active in the Kuskokwim River area near McGrath. The company found gold in stream sediments in the same belt as the $31,300 \mathrm{~kg}$ (1 million oz) Vinasale Mountain gold deposit, which is hosted in quartz monzonite and the $10,885 \mathrm{~kg}(350,000 \mathrm{oz})$ Nixon Fork gold skarn deposit.

Recent activity at the Casino porphyry copper-gold deposit in the Yukon Territory created new interest in several similar targets in Alaska. Noranda Exploration Inc., operating on behalf of Hemlo Gold Mines Inc., commissioned a 460-line-km (300-line-mi) airborne magnetic-electromagnetic-radiometric and VLF-EM geophysical survey on the Taurus property in 1992. The survey identified several "blind" targets beneath the extensive overburden, one of which was being drilled (February 1993), and added a new south zone to the east and west Taurus zones which were the focus of exploration during the early 1970 s.

Noranda/Hemlo is also a partner in a joint venture with Watts, Griffis and McQuat Inc. (WGM), Conroy Petroleum and Natural Resources Plc. of Ireland, and the American subsidiary of Sumitomo Metal Mining of Japan. This joint venture, announced late 1992, is to explore a large area around WGM's Stone Boy Creek Project about $160 \mathrm{~km}(100 \mathrm{mi})$ east of Fairbanks.

Following 4,000 line $\mathrm{km}(2,500$ line mi) of airborne magnetic/EM survey flown in 1991 and 1992, several igneous-hosted gold and sedimentary-exhalative targets have been identified for further evaluation, mainly on state-owned lands.

\section{Southwestern Alaska}

There were ten small placer exploration projects and two large hard-rock gold exploration programs throughout southwestern Alaska in 1992. Placer Dome U.S. Inc. continued exploration in the Flat area with geological investigations and trenching. At its Pebble Copper deposit near Lake nliamna, Cominco Alaska Exploration Inc. drilled $2,000 \mathrm{~m}(6,606 \mathrm{ft})$ to further evaluate this large copper-gold porphyry system. Reported reserves are 450 million tonnes ( 500 million tons) grading 0.35 percent copper and $0.012 \mathrm{oz} /$ ton ( $0.41 \mathrm{~g} /$ tonne) gold, with a higher-grade 50-million-ton core grading 0.4 percent copper with $0.015 \mathrm{oz} /$ ton $(0.51 \mathrm{~g} /$ tonne) gold. Molybdenum occurs with grades in the 0.03 to 0.04 percent range.

\section{Southcentral Alaska}

Ten small placer exploration programs were reported throughout southcentral Alaska in 1992. Rowallen Mine Partnership collected a bulk sample upstream of the Valdez Creek placer mine. In the same area Canalaska Resources USA Ltd. continued mapping and sampling at its Rainbow Hill hard-rock prospect.

Modest programs were reported in the Willow district at the Gold Cord Mine, in the Upper Chulitna district at the Golden Zone Mine, and in the Yentna district at the Blue Ribbon Mine. The largest exploration program in this area was at the Johnson River prospect where a 460-line- $\mathrm{km}$ (300-line-mi) geophysical survey and a $2,652 \mathrm{~m}(8,700 \mathrm{ft})$ drill program was designed to explore extensions of the existing reserve of 126,980 tonnes $(140,000$ tons $)$ of zine and $16,800 \mathrm{~kg}$ $(540,000 \mathrm{oz})$ of gold.

North Pacific Mining Co. had a small exploration project on the Toklat polymetallic prospect in the Talkeetna Mountains. The company also collected a bulk sample from the Red Mountain chromite deposit near Seldovia for metallurgical testing.

The Australian exploration firm Paraclete Resources explored gold-magnetite-ilmenite strandline deposits near Cape Yakataga. The objective is to delineate a resource of placer gold with byproduct industrial minerals such as ilmenite and magnetite.

\section{Alaska Peninsula}

Except for claim assessment, no exploration activity was reported on the Alaska Peninsula in 1992.

\section{Southeastern Alaska}

In southeastern Alaska, Curator International conducted target evaluation at its Jualin prospect, about $80 \mathrm{~m}$ (50 mi) north of Juneau, adjacent to Echo Bay's Kensington Mine.

Work continued at Kensington, a joint venture of Echo Bay and Coeur d'Alene Mines, with Echo Bay acting as operator. The joint venture has spent over $\$ 80$ million on the project through 1992 . Reserves for the Kensington through 1991 are 10.4 million tonnes ( 11.5 million tons) at $4.9 \mathrm{~g} /$ tonne $(0.143 \mathrm{oz}$ ) gold. The Horribie Vein mineralized zone which is intersected by Kensington main adit contains an additional 3.56 million tonnes ( 3.9 million tons) of $3.8 \mathrm{~g} /$ tonne $(0.11 \mathrm{oz} /$ ton) gold.

The final environmental impact statement (EIS) for the project was released in the spring of 1992. The document estimates a $\$ 205$ million capital cost with a production cash-cost of $\$ 213 / \mathrm{oz}$ gold. The mine would be a rotational camp operation staged from Juneau. Since the mine is in the Greater Juneau Borough the mine operation falls under the City and Borough Mining Ordinance. In October 1992, the City and Borough of Juneau (CBJ) Planning Commission approved the conditional use permit (equivalent to a final EIS) for the project. The joint venture continues to move forward with permitting details of the project and will undertake 


\section{Distribution of exploration expenditures by areas of the state. Exploration expenditures for 1992 totaled $\$ 30.4$ million.}

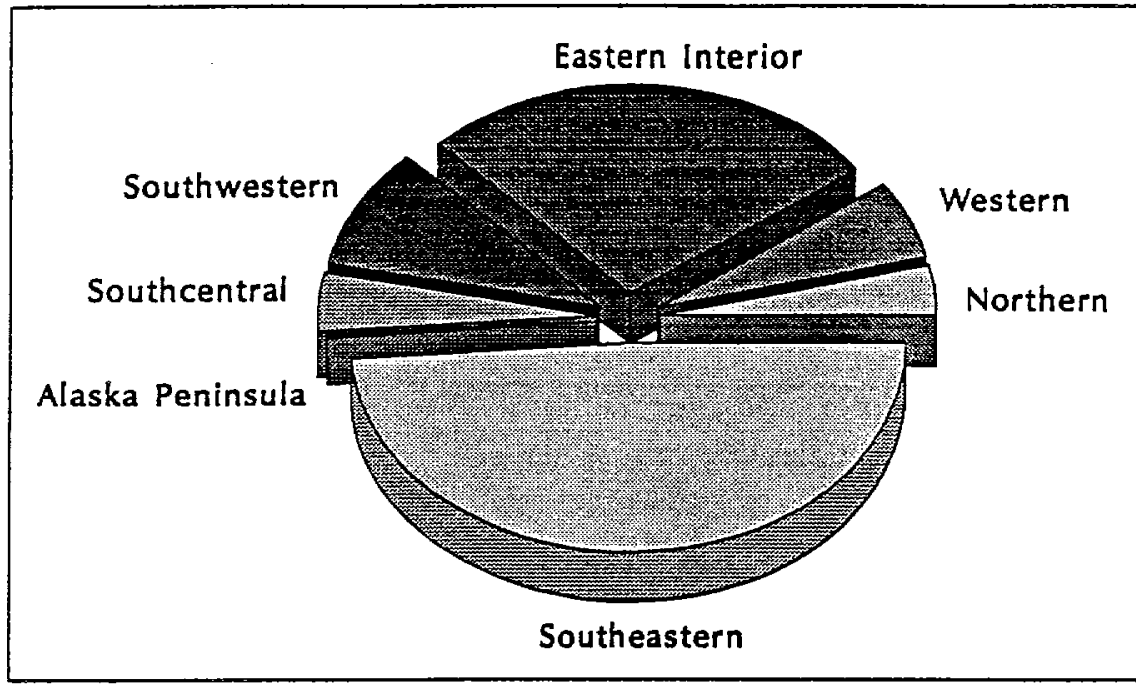

additional underground exploration in 1993 in an effort to expand the ore reserve.

Echo Bay continues its six-year effort to reopen the Alaska-Juneau (A-J) mine, one of Alaska's premier gold producers. Between 1886 and mine closure in 1944 , the mine produced $105,740 \mathrm{~kg}$ ( 3.4 million oz) of gold, $68,420 \mathrm{~kg}$ ( 2.2 million oz) of silver, and 19.95 million $\mathrm{kg}$ (44 million lbs) of lead. The mine closed because of wartime shortages in labor and material and not due to ore depletion.

Reserves in all categories for the A-J mine approach 90.7 million tonnes ( 100 million tons) grading about $1.75 \mathrm{~g} /$ tonne $(0.05 \mathrm{oz} / \mathrm{ton})$ gold. These reserves exceed the production threshold of Echo Bay, therefore only limited underground work was conducted in 1992.

During 1992, the final EIS was released for the A-J mine project. In addition, Echo Bay purchased the 15 percent interest in the project which was held by WGM Inc. Thus, Echo Bay now has complete interest in both the A-J and Treadwell gold deposits, although CBJ retains a royalty interest. As with the Kensington mine, the A-J mine must obtain a conditional-use permit under the Juneau Mining Ordinance. The CBJ Planning Commission has recently begun deliberations on the A-J mine and the process should be completed by April 1993.

\section{Drilling}

Total drilling in Alaska in 1992 was $135,468 \mathrm{~m}$ $(444,449 \mathrm{ft})$, compared with $157,909 \mathrm{~m}(514,796 \mathrm{ft})$ reported in 1991. Total reported hard-rock diamonddrilling and reverse-circulation drilling, at 109,677 m $(359,834 \mathrm{ft})$, was up substantially from the 1991 level of $96,516 \mathrm{~m}(316,655 \mathrm{ft})$.

Projects reporting major drilling programs include the Rock Creek area north of Nome; Ilinois Creek in the Kaltag area; the Pebble Copper and Johnson River programs near Cook Inlet; the Ryan Lode, Ester Dome,
Pedro Dome, and Fort Knox programs in the Fairbanks area; and the Kensington and Greens Creek Mines in Southeast Alaska.

Although total drilling was down from 1991, most of the difference was in thaw-field drilling at Nome by Alaska Gold Co. Because the company is converting from dredging to open-pit operations, thaw-field drilling is no longer necessary. 


\section{Government Action}

For several years the state has been compiling a register of the trails that may qualify as access corridors under the Revised Statute 2477 (RS2477). During 1992, the state defined a procedure whereby an individual can nominate to the state a trail for consideration as an RS2477 route.

Municipal taxation of in-place mineral resources within municipality borders in Alaska has been possible since statehood. In May 1992, the Alaska Legislature passed SB330, which provides a permanent exemption from municipal taxation of in-place mineral resources.

In 1992 there was no resolution to the problem of recreating the Mental Health Land Trust, but an escrow mechanism was designed so that no project was unduly delayed by the lawsuit between the state and the Mental Health Trust plaintiffs.

After two seasons of field-checking the mineral resources of available federal land, in late 1992 the state submitted land selections of the remaining statehood land entitlement of about 5.7 million hectares (20 million acres). When finally transferred, the state will own about 42.1 million hectares (104 million acres), administered by the Department of Natural Resources.

Because the State of Alaska intends to complete its land selection by January 1994, those individuals or companies holding federal claims wanting to convert to state ownership should do so as soon as possible. ("How to Convert Federal Mining Claims to State Claims," page 11 of this report.)

\section{NEW RENTAL FEE ON FEDERAL MINING CLAIMS}

On October 5, 1992, the Department of the Interior Appropriation Act for Fiscal Year 1993 was signed into law. This new law pertains to federal mining claims only, and does not affect state mining claims in any way. Following are the highlights of the act:

\section{New Mining Claims}

(a) Owners of new mining claims located on or after October 6,1992, will be charged a new rental fee of $\$ 100$ in addition to the existing service charge of $\$ 10$. This payment must be made when filing the mining claim notice with Bureau of Land Management (BLM) within 90 days of staking the new claim. The rental payment is for the assessment year ending September 1, 1993.

(b) A rental payment of $\$ 100$ for the 1994 assessment year (beginning September 1, 1993) must be paid to BLM no later than August 31, 1993. Assessment work is not required to be performed for the 1993 and 1994 assessment years.

Claimants with more than ten claims

Owners of more than ten federal mining claims located on or before October 5, 1992, must pay BLM a rental of $\$ 200$ per claim no later than August 31, 1993. These are the rental payments for the 1993 and 1994 assessment years. Assessment work is not required to be performed for the 1993 and 1994 assessment years.

\section{Claimants with ten claims or fewer}

The "Small Miner Exemption" of the Act provides two choices for claim owners of ten claims or less.

CHOICE 1: The owner of mining claims located on or before October 5, 1992, can pay BLM a rental of $\$ 200$ per claim no later than August 31, 1993. These are the rental payments for the 1993 and 1994 assessment years. If the payment is made, assessment work is not required to be performed for the 1993 and 1994 assessment years.

CHOICE 2: The owner of mining claims located on or before October 5, 1992 is exempt from paying the $\$ 200$ rental fee for any of the following reasons:

(a) The claimant is mining under a valid notice or plan of operations and producing not less than $\$ 1,500$ and not more than $\$ 800,000$ in gross revenues per year.

(b) The claimant is exploring the claims under a valid notice or plan of operation.

(c) The claimant must have less than ten acres of unreclaimed surface disturbance from such mining activity or exploration work.

(d) In addition, all claimants exempted from paying 
the $\$ 200$ rental fee must file two newly-required certifications by August 31, 1993. (1) A certificate showing that the claimant qualifies for the exemption. (2) A certificate stating that performance of the 1993 assessment work has been done and that the 1994 assessment work will be performed between September 1, 1993, and September 1, 1994.

Please note: At the time of this writing, BLM has not yet issued its final ruling. Interested miners are urged to contact BLM for further details regarding the Interior Appropriations Act.

\section{HOW TO CONVERT FEDERAL MINING CLAIMS TO STATE CLAIMS}

With the Interior Appropriations Act recently signed into law, several owners of federal mining claims have inquired about the possibility and procedure for converting a federal mining claim to a state mining claim. In some cases it is possible to do this, but only if a number of land status conditions are met.

\section{CHECK THE LAND STATUS}

The following checklist is for owners of unsurveyed federal mining claims who are considering converting their claims to state claims:

(1) Are your federal claims surrounded by land already conveyed to the state? If not, keep your federal claims.

(2) Is mining permitted on the state land surrounding your claims? If not, keep your federal claims.

(3) Are there state or federal claims located in conflict with your federal claims? If yes, you should resolve those conflicts before you proceed.

\section{HOW TO CONVERT UNSURVEYED FEDERAL CLAIMS}

If your answers for questions (1) and (2) are yes, and your answer to question (3) is no, then this is what you have to do:

(a) Record a Notice of Abandonment with the appropriate District Recorder and deliver a copy to the Bureau of Land Management (BLM). (b) Immediately locate and record state mining claims to cover the abandoned claims.

(c) Since your new claims are on state-selected land, you are not required to make the $\$ 20$-claimrental payment to the state. However, you must make this payment within 90 days of the date the land is conveyed to state ownership. Therefore, you are well advised to make a $\$ 20$ rental deposit now. This nonrefundable deposit will be applied to the first rental year once the land is conveyed to the state.

(d) Submit a Priority Tentative Approval (T.A.) request to the State Division of Mining. This will notify the state of your need to have the land conveyed as soon as possible.

(e) There is no way of knowing how long it will take BLM to process a specific Priority T.A. request. If the abandonment of the federal claims is made near the end of the mining season, the government will have all winter to process the conveyance to the state.

(f) The miner should be aware that there is no guarantee that the land will be conveyed to the state by the beginning of the following mining season, nor can the state guarantee the claim owner that the land eventually will be conveyed.

Changing the underlying ownership of mining ground from the federal to the state government is not a simple process nor without risk. It involves abandoning the federal mining claim with its grandfather rights and patent rights and locating new state mining claims in place of the federal claim.

Further information can be obtained at the following offices:
Alaska Division of Mining
Frontier Building
36 C Street, Suite 880
Anchorage, AK 99503
(907) 762-2518
$1-800-478-2154$
Alaska Division of Mining
3700 Airport Way
Fairbanks, AK 99709
(907) $451-2788$ 



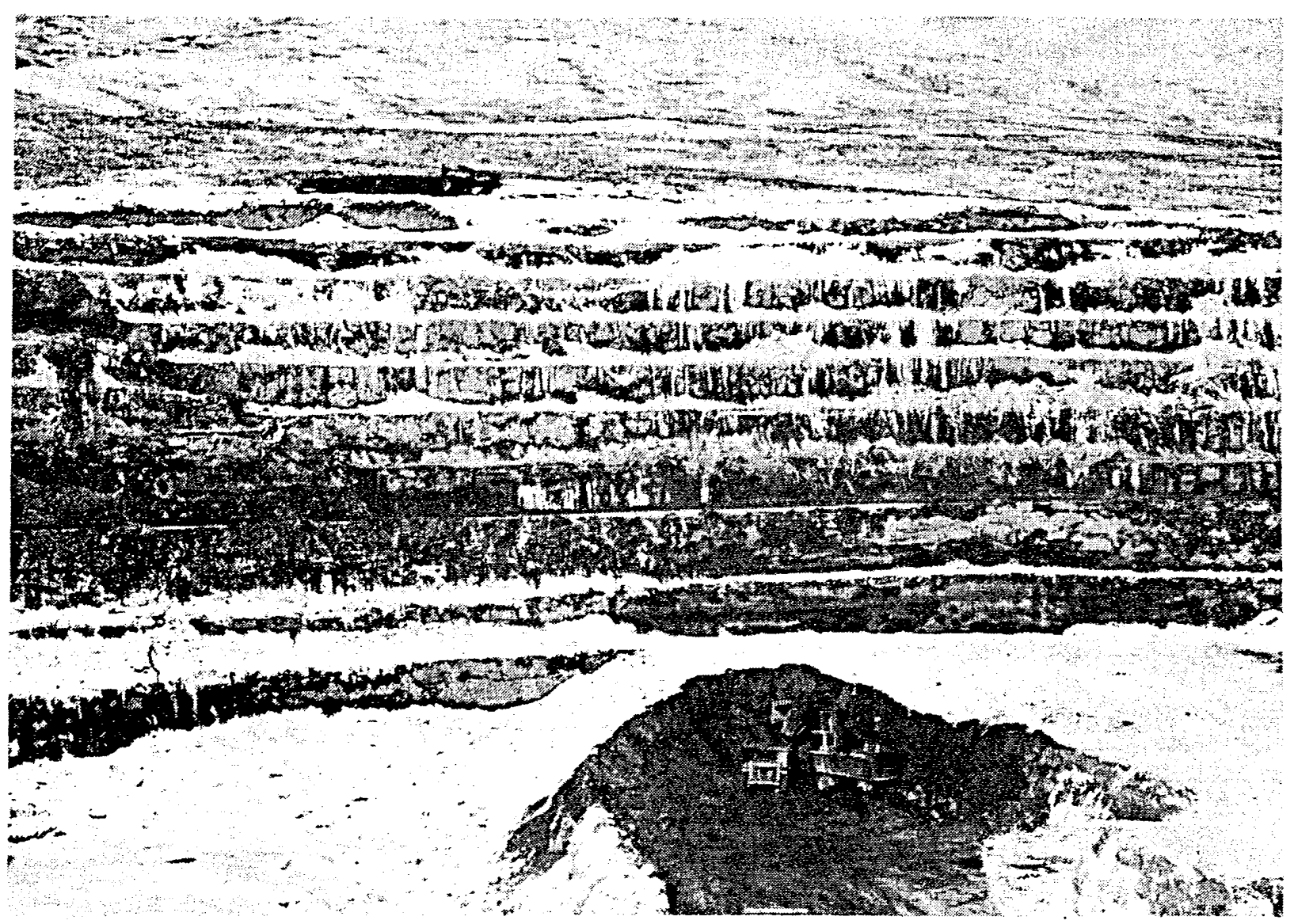

The Valdez Creek Mine, $80 \mathrm{~km}$ (50 mi) east of Cantwell, Alaska, has been the state's largest gold producer for seven of the last eight years. Cambior Alaska Inc. operates the mine, which produced 2,676 kg $(86,052 \mathrm{oz})$ refined gold and provided 155 full-time equivalent jobs in 1992. The photo of pit A-7-IX of the mine looks north to the diversionary-ditch road. Photo courtesy of Cambior Alaska Inc.

Front cover: Processing mill of the Golden Zone Mine in the Chulitna-Cache Creek District northwest of Talkeetna, southcentral Alaska. Prior to World War II, the mine produced copper, gold, and silver from underground working. Recent mineral exploration has proved up an estimated 7,153 $\mathrm{kg}(230,000 \mathrm{oz})$ gold in about 1.9 million tonnes ( 2 million tons) of ore. Photo courtesy of Mr. Richard Hughes.

\section{DEPARTMENT OF NATURAL RESOURCES}

Division of Geological \& Geophysical Surveys Division of Mining

\section{DEPARTMENT OF COMMERCE AND ECONOMIC DEVELOPMENT Division of Economic Development}

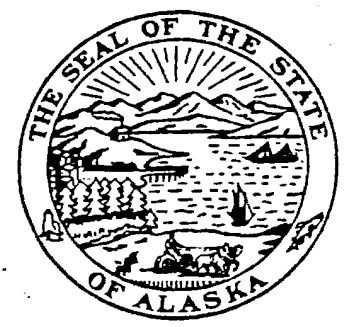

